\title{
Two-Photon Near Infrared Fluorescent Turn-On Probe Toward Cysteine and Its Imaging Applications
}

Junfeng Wang, ${ }^{\dagger}$ Bin Li, ${ }^{\dagger}$ Weiyu Zhao, ${ }^{\dagger}$ Xinfu Zhang, ${ }^{\dagger}$ Xiao Luo, ${ }^{\dagger}$ Mark E. Corkins, ${ }^{\ddagger}$ Sara L. Cole, ${ }^{\S}$ Chao Wang," Yi Xiao," Xiaoman Bi, ${ }^{\perp}$ Yi Pang, ${ }^{\perp}$ Craig A. McElroy, ${ }^{\dagger}$ Amanda J. Bird, ${ }^{\ddagger}$ Yizhou Dong ${ }^{*}+$

${ }^{\dagger}$ Division of Pharmaceutics \& Pharmaceutical Chemistry, College of Pharmacy, ${ }^{\ddagger}$ Department of Molecular Genetics, and ${ }^{\S}$ Campus Microscopy and Imaging Facility, The Ohio State University, Columbus, Ohio 43210, United States "State Key Laboratory of Fine Chemicals, Dalian University of Technology, Dalian 116024, P. R. China ${ }^{\perp}$ Department of Chemistry \& Maurice Morton Institute of Polymer Science, The University of Akron, Akron, Ohio 44325, United States

\section{Table of Contents}

General synthetic procedures and spectral data

Figure S1, Figure S2 and Figure S3

Figure S4 and Figure S5

Figure S6 and Figure S7

Figure S8

Figure S9

Figure S10 and Figure S11 


\section{General synthetic procedures and spectral data:}

Synthesis of compound 4. 1-(2-hydroxyphenyl)ethanone 2 (5 g, $36.8 \mathrm{mmol}$ ) was dissolved in $100 \mathrm{~mL}$ ethyl acetate, and then sodium (4 g, $173.9 \mathrm{mmol}$ ) was added into the solution. The grayish-green solid was filtered after violently stirring for 4h at ambient temperature. The solid was dissolved in $100 \mathrm{~mL}$ deionized water, followed by the adjustment of $\mathrm{pH}$ of the solution to neutral. The aqueous solution was extracted with $200 \mathrm{~mL}$ EtOAc and the organic layers were dried over $\mathrm{Na}_{2} \mathrm{SO}_{4}$, filtered, and concentrated to yield the final crude product 3 as a brown solid (4 g, $57 \%$ ), which was recrytallized as white powder in Hexanes:EtOAc (4:1). Compound 3 (4 g) was dissolved in AcOH solution (52 mL), then sulfuric acid $(2.4 \mathrm{~mL})$ was slowly added into the solution. The resulting mixture was refluxed for about 20 min until 3 was consumed (monitored by TLC, EtOAc:Hexanes = 1:3). The acid solution was then poured into $700 \mathrm{~mL}$ ice water, followed by the adjustment of $\mathrm{pH}$ of the solution to neutral with $\mathrm{Na}_{2} \mathrm{CO}_{3}$. The aqueous solution was extracted with methylene dichloride twice and the organic layers were dried over $\mathrm{Na}_{2} \mathrm{SO}_{4}$, filtered, and concentrated to yield the final crude product $\mathbf{4}$ as colorless crystals (3.1 g, 87.2\%). ${ }^{1} \mathrm{H}$ NMR (400 MHz, $\mathrm{CDCl}_{3}$ ): $\delta 8.20$ (1H, ddd, $J=0.4 \mathrm{~Hz}, J=1.6 \mathrm{~Hz}, J=8.0 \mathrm{~Hz}$ ), 7.65 $(1 \mathrm{H}, \mathrm{dt}, J=1.6 \mathrm{~Hz}, J=8.4 \mathrm{~Hz}), 7.43(1 \mathrm{H}, \mathrm{ddd}, J=0.4 \mathrm{~Hz}, J=1.6 \mathrm{~Hz}, J=8.0 \mathrm{~Hz}), 7.39(1 \mathrm{H}, \mathrm{dt}, J=1.0 \mathrm{~Hz}, J=7.2 \mathrm{~Hz})$, $6.19(1 \mathrm{H}, \mathrm{s}), 2.41(3 \mathrm{H}, \mathrm{s})$.

Synthesis of compound 5. 2-methyl-4H-chromen-4-one 4 (2.35 g) and malononitrile (1.35 g) were dissolved in $10 \mathrm{~mL}$ acetic anhydride. The solution was refluxed for 17 hours and then the solvent was evaporated in vacuo. Deionized water $(40 \mathrm{~mL})$ was added to the residue and the mixture was refluxed for another $0.5 \mathrm{~h}$, followed by extraction with methylene dichloride. The organic layers were dried over $\mathrm{Na}_{2} \mathrm{SO}_{4}$, filtered, and concentrated. The obtained crude product was purified by silica column chromatography to yield compound 5 as an orange solid (1.28 g, $42 \%$ yield). ${ }^{1} \mathrm{H}$ NMR (400 $\mathrm{MHz}_{\mathrm{CDCl}}$ ): $\delta 8.94(1 \mathrm{H}, \mathrm{dd}, J=1.6 \mathrm{~Hz}, J=9.2 \mathrm{~Hz}), 7.34(1 \mathrm{H}, \mathrm{dt}, J=1.6 \mathrm{~Hz}, J=7.2 \mathrm{~Hz}), 7.48(1 \mathrm{H}, \mathrm{d}, J=7.2 \mathrm{~Hz}), 7.47$ $(1 \mathrm{H}, \mathrm{dt}, J=1.2 \mathrm{~Hz}, J=7.2 \mathrm{~Hz}), 6.74(\mathrm{~s}, 1 \mathrm{H}), 2.46(3 \mathrm{H}, \mathrm{s})$.

Synthesis of compound 1. 2-(2-methyl-4H-chromen-4-ylidene) malononitrile 5 (400 mg), and 4-hydroxybenzaldehyde $(300 \mathrm{mg})$ were dissolved in toluene $(34 \mathrm{~mL})$ with piperidine $(0.6 \mathrm{~mL})$ and acetic acid $(0.6 \mathrm{~mL})$ under nitrogen protection at room temperature. The resulting mixture was refluxed for 17 hours. Then the reaction mixture was cooled to room temperature and condensed. The obtained crude product was purified by silica column chromatography to yield compound 1 as a red solid (252 mg, 42\% yield). ${ }^{1} \mathrm{H}$ NMR (400 MHz, $\left.\mathrm{CD}_{3} \mathrm{OD}\right): \delta 8.88(1 \mathrm{H}, \mathrm{dd}, J=1.2 \mathrm{~Hz}, J=8.4 \mathrm{~Hz}), 7.85(1 \mathrm{H}, \mathrm{dt}$, $J=1.2 \mathrm{~Hz}, J=7.2 \mathrm{~Hz}), 7.73(1 \mathrm{H}, \mathrm{s}), 7.70(1 \mathrm{H}, \mathrm{dd}, J=1.2 \mathrm{~Hz}, J=7.5 \mathrm{~Hz}), 7.59(2 \mathrm{H}, \mathrm{d}, J=8.4 \mathrm{~Hz}), 7.53(1 \mathrm{H}, \mathrm{dt}, J=1.2$ $\mathrm{Hz}, J=7.2 \mathrm{~Hz}), 6.95(1 \mathrm{H}, \mathrm{d}, J=15.9 \mathrm{~Hz}), 6.87(1 \mathrm{H}, \mathrm{d}, J=15.9 \mathrm{~Hz})$ overlapping with $6.89(1 \mathrm{H}, \mathrm{d}, J=4.2 \mathrm{~Hz})$ and 6.86 $(1 \mathrm{H}, \mathrm{d}, J=4.2 \mathrm{~Hz})$. ESI-MS Calc. for $\mathrm{C}_{20} \mathrm{H}_{11} \mathrm{~N}_{2} \mathrm{O}_{2}$, [M-H]', 313.0826, found, 311.0809.

Synthesis of probe TP-NIR. Compound 1 (100 mg) was dissolved in DCM (5 mL) followed by addition of TEA (90 mg), then acryloyl chloride (117 mg) was added slowly. The resulting mixture was stirred at room temperature for $10 \mathrm{~min}$. Probe TP-NIR was purified by silica column chromatography (DCM:Hexanes $=7: 3$ ) as yellow solid in $92 \%$ yield. ${ }^{1} \mathrm{H}$ NMR (400 MHz, $\left.\mathrm{CDCl}_{3}\right): \delta 8.94(1 \mathrm{H}, \mathrm{dd}, J=1.2 \mathrm{~Hz}, J=8.4 \mathrm{~Hz}), 7.77(1 \mathrm{H}, \mathrm{dt}, J=1.2 \mathrm{~Hz}, J=7.2 \mathrm{~Hz}), 7.66-7.62(3 \mathrm{H}$, overlapping), 7.59 (1H, dd, $J=1.2 \mathrm{~Hz}, J=8.4 \mathrm{~Hz}$ ), $7.48(1 \mathrm{H}, \mathrm{dt}, J=1.2 \mathrm{~Hz}, J=7.2 \mathrm{~Hz}), 7.66-7.62$ (2H, overlapping), $6.90(1 \mathrm{H}, \mathrm{s}), 6.81(1 \mathrm{H}, \mathrm{d}, J=16.0 \mathrm{~Hz}), 6.67(1 \mathrm{H}, \mathrm{dd}, J=1.2 \mathrm{~Hz}, J=17.2 \mathrm{~Hz}), 6.36(1 \mathrm{H}, \mathrm{q}, J=8.4 \mathrm{~Hz}), 6.08(1 \mathrm{H}, \mathrm{dd}, J=$ $1.2 \mathrm{~Hz}, J=8.4 \mathrm{~Hz}) .{ }^{13} \mathrm{C}$ NMR $\left(100 \mathrm{MHz} \mathrm{CDCl}_{3}\right): \delta 164.2,157.2,152.8,152.3,152.2,137.7,134.7,133.2,132.4,129.1$, 127.6, 126.0, 125.9, 122.4, 118.9, 118.6, 117.8, 116.7, 115.6, 107.0. ESI-MS Calc. for $\mathrm{C}_{23} \mathrm{H}_{15} \mathrm{~N}_{2} \mathrm{O}_{3},[\mathrm{M}+\mathrm{H}]^{+}, 367.11$, found, 367.10 . 

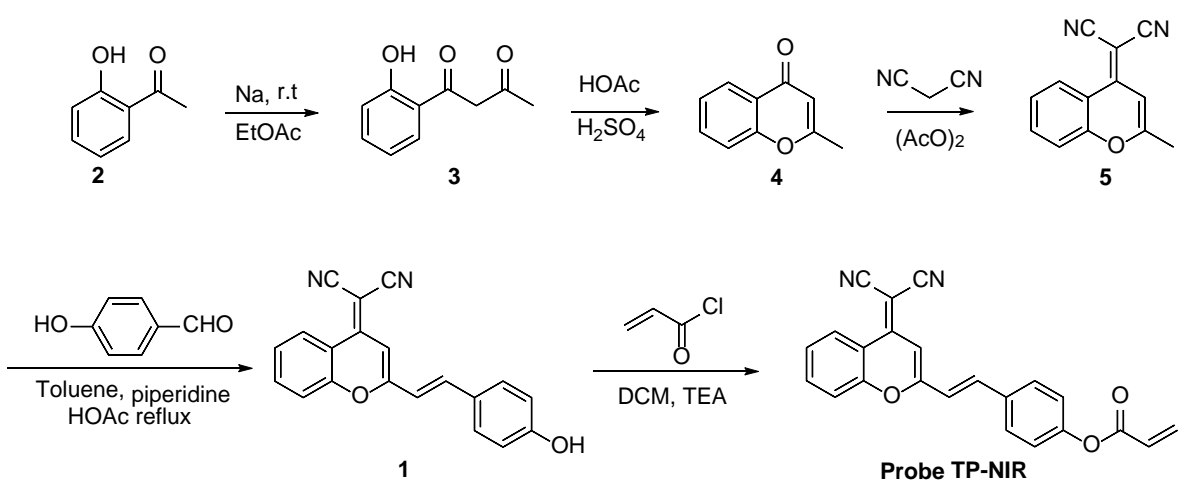

Figure S1. Synthetic scheme for probe TP-NIR. TP-NIR was synthesized through acylation of dicyanomethylene-4Hpyran derivative $\mathbf{1}$ with acryloyl chloride.

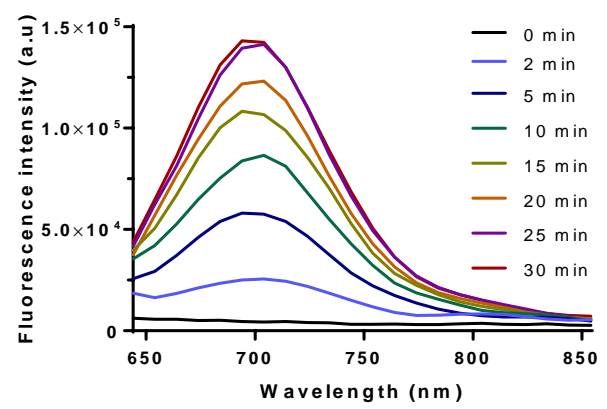

Figure S2. Fluorescent response of TP-NIR $(10 \mu \mathrm{M})$ in PBS buffer $(\mathrm{pH}=7.4)$ containing $50 \%$ of DMSO upon addition of $100 \mu \mathrm{M}$ of Cys over time at RT (Excitation wavelength, $557 \mathrm{~nm}$ ).

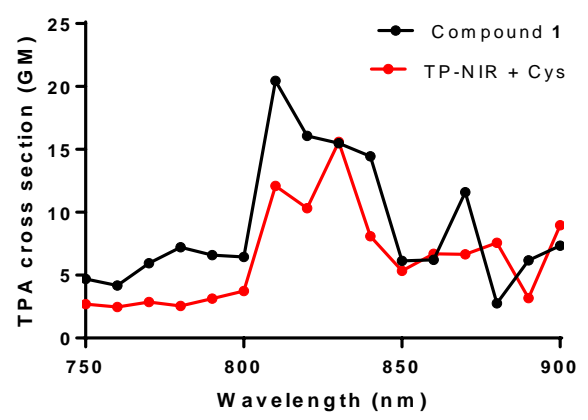

Figure S3. Two-photon absorption spectrum of compound $1(100 \mu \mathrm{M})$ and the product of the reaction of TP-NIR (100 $\mu \mathrm{M})$ with Cys $(500 \mu \mathrm{M})$ incubated in PBS buffer $(\mathrm{pH}=7.4)$ containing $50 \%$ of DMSO for $30 \mathrm{~min}$ at RT. 


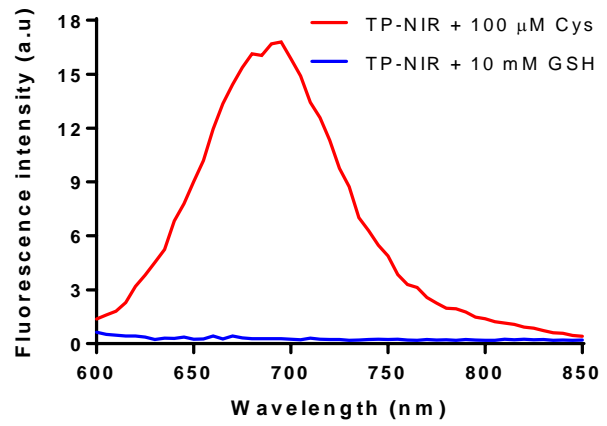

Figure S4. Fluorescent spectra of TP-NIR $(10 \mu \mathrm{M})$ in PBS buffer $(\mathrm{pH}=7.4)$ containing 50\% of DMSO upon addition of $100 \mu \mathrm{M}$ of Cys or $10 \mathrm{mM}$ of GSH for $30 \mathrm{~min}$ at RT (Excitation wavelength, $557 \mathrm{~nm}$ ).

(a)

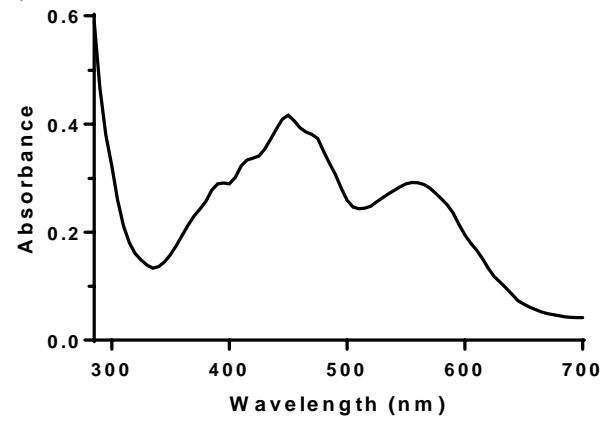

(b)

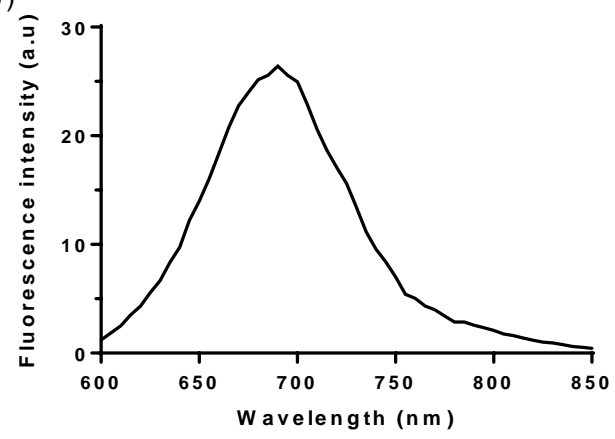

Figure S5. UV-vis (a) and fluorescent spectra (b) of compound $1(10 \mu \mathrm{M})$ in PBS buffer $(\mathrm{pH}=7.4)$ containing $50 \%$ of DMSO (Excitation wavelength, $557 \mathrm{~nm})$. 
(a)

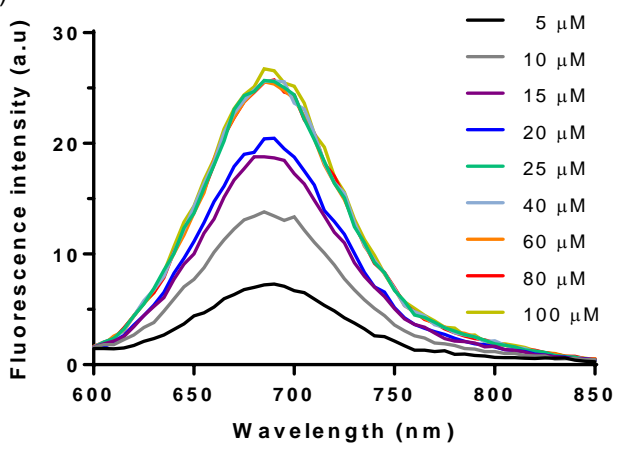

(b)

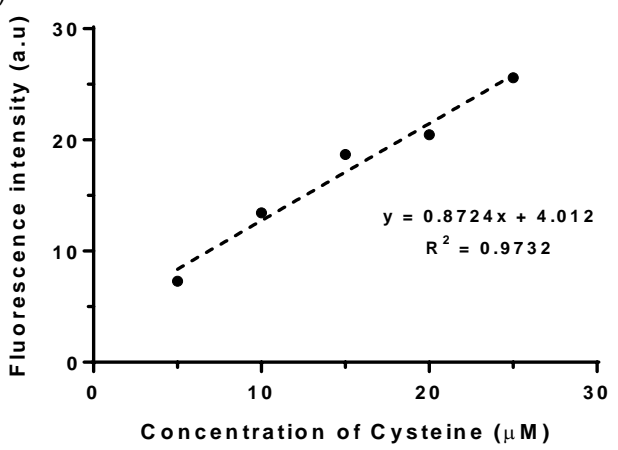

Figure S6. Fluorescence response of TP-NIR to Cys. (a) Fluorescence spectra of TP-NIR (10 $\mu \mathrm{M})$ in PBS buffer (pH = 7.4) containing 50\% of DMSO upon addition of different concentrations of Cys (from 5 to $100 \mu \mathrm{M}$ ) at RT for 30 min (Excitation wavelength, $557 \mathrm{~nm}$ ). (b) The linear correlation between the fluorescence intensity and the concentrations of Cys. The detection limit of TP-NIR toward Cys was determined with the formula: $3 \sigma / \mathrm{k}$, Where $\sigma$ is the standard deviation of blank measurement, $\mathrm{k}$ is the slope between the fluorescence intensity versus concentration.

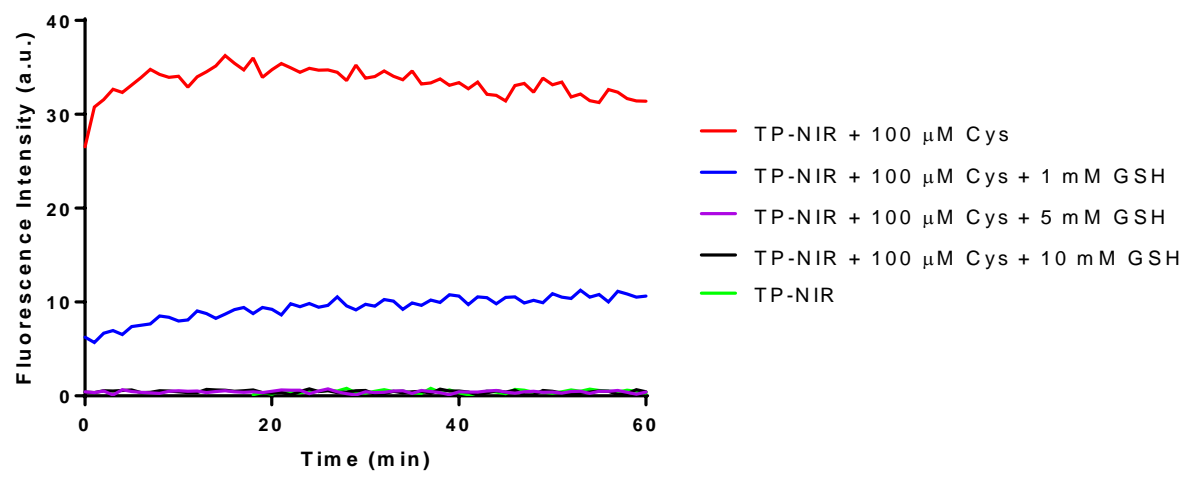

Figure S7. Reaction kinetics of TP-NIR under different conditions (excitation wavelength 557 nm; emission wavelength $690 \mathrm{~nm})$. 
(a)
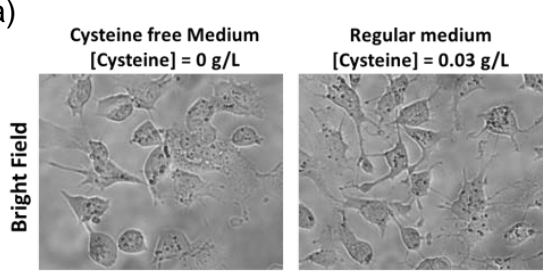

Cysteine high medium

[Cysteine] $=0.3 \mathrm{~g} / \mathrm{L}$
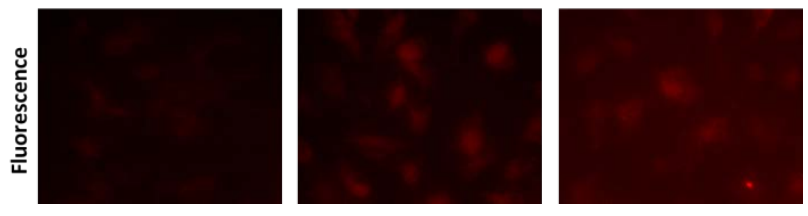

(b)

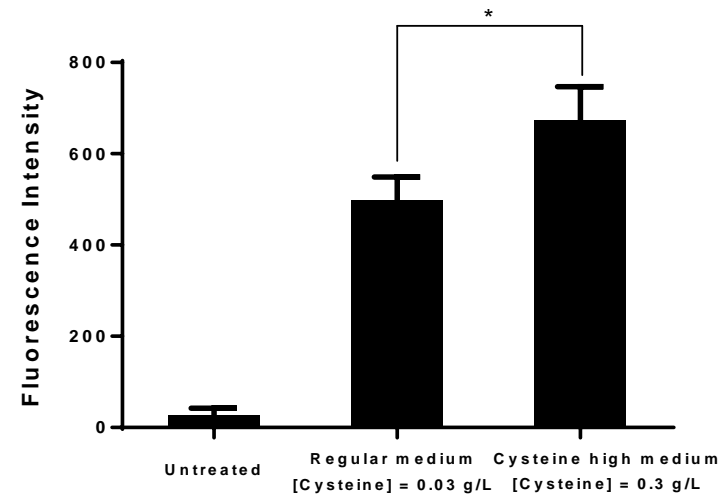

Figure S8. The effect of cysteine concentration on florescence signal of TP-NIR. (a) Florescence imaging and (b) flow cytometry analysis ( $n=3 ; *, p<0.05$; $t$ test, double-tailed; untreated cells serve as a control group) of TP-NIR treated Hep 3B cells incubated in cysteine free medium, regular medium and cysteine high medium. 
(a)

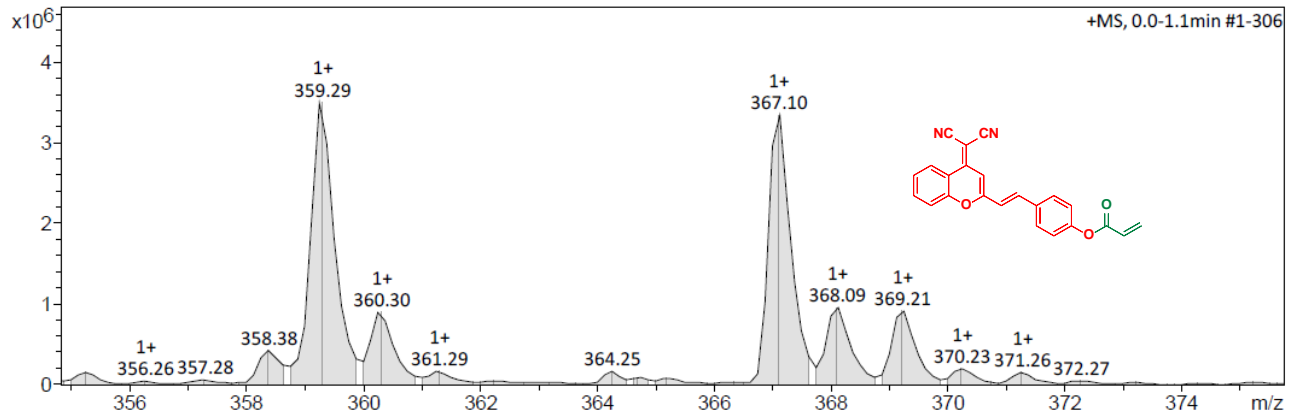

(b)

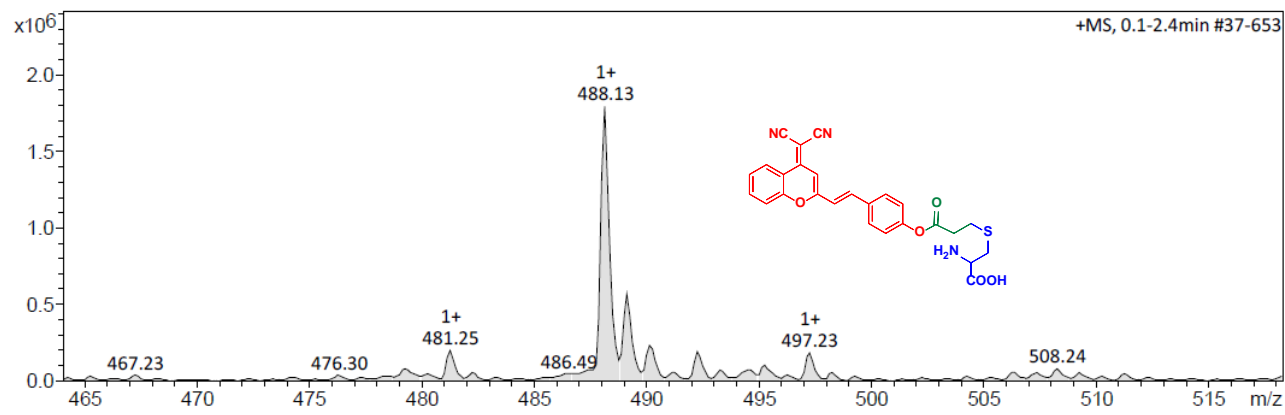

(c)
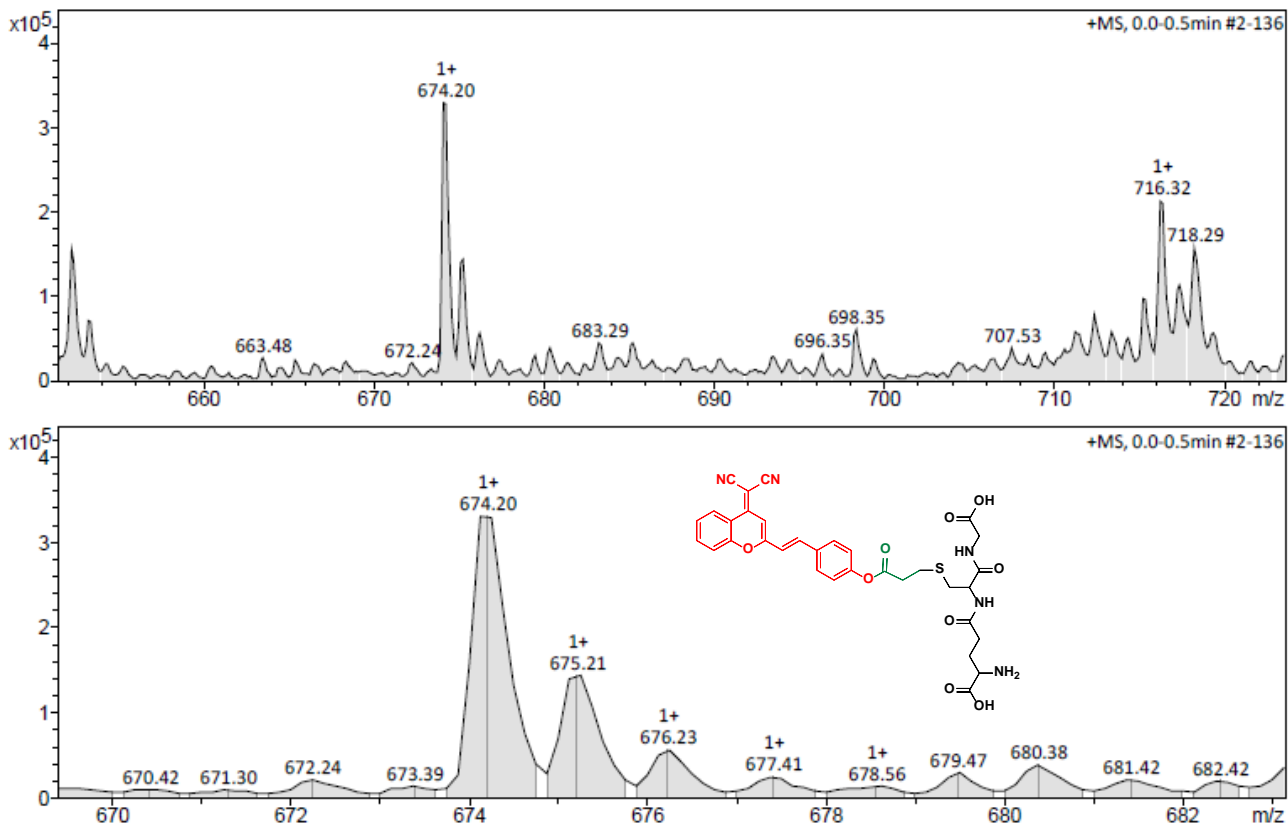

Figure S9. ESI mass spectrum of the target compound TP-NIR (Calc. for $\mathrm{C}_{23} \mathrm{H}_{15} \mathrm{~N}_{2} \mathrm{O}_{3},[\mathrm{M}+\mathrm{H}]^{+}, 367.11$ ) (a), the intermediate TP-NIR-Cys (Calc. for $\mathrm{C}_{26} \mathrm{H}_{22} \mathrm{~N}_{3} \mathrm{O}_{5} \mathrm{~S}$, $[\mathrm{M}+\mathrm{H}]^{+}$, 488.13) of TP-NIR and Cys (b), and the reaction product TPNIR-GSH (Calc. for $\mathrm{C}_{33} \mathrm{H}_{32} \mathrm{~N}_{5} \mathrm{O}_{9} \mathrm{~S}$, [M+H] $]^{+}$, 674.19) of TP-NIR and GSH (c). 


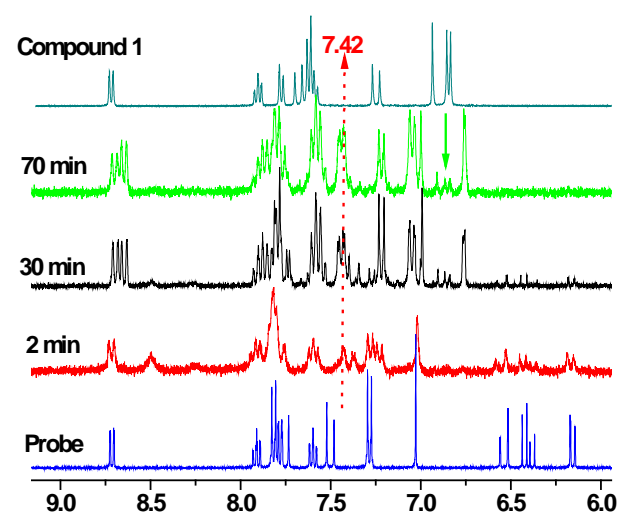

Figure S10. In situ ${ }^{1} \mathrm{H}$ NMR spectra of TP-NIR upon addition of 10 equiv. GSH over time in $d_{6}$-DMSO: $\mathrm{D}_{2} \mathrm{O}=$ 9:1.

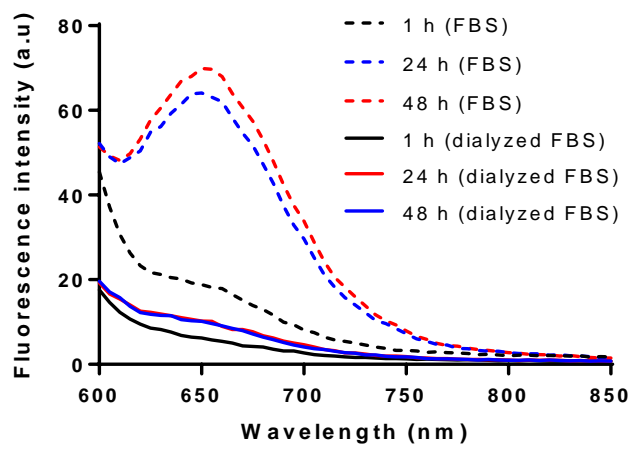

Figure S11. The serum stability of TP-NIR. Probe TP-NIR $(10 \mu \mathrm{M})$ dissolved in DMSO was incubated with equal volume of commercial fetal bovine serum or dialyzed fetal bovine serum against PBS buffer $(\mathrm{pH}=7.4)$. At the indicated time points, the fluorescent spectra of the mixture was measured (Excitation wavelength, $557 \mathrm{~nm}$ ). 
(a)
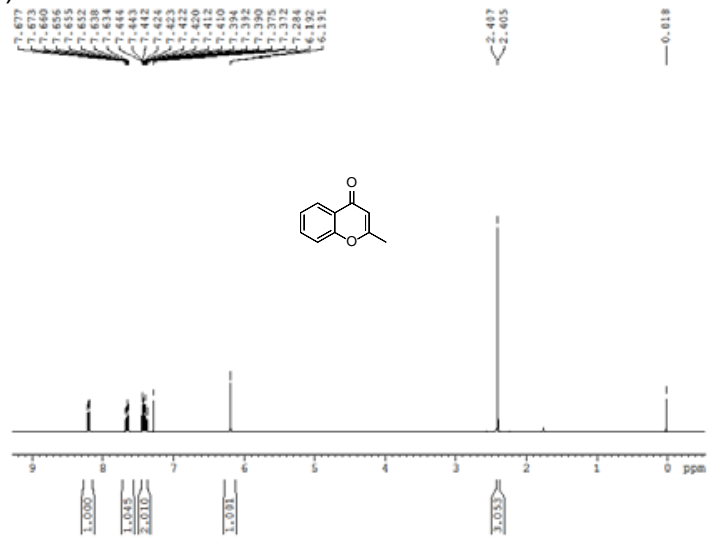

(c)

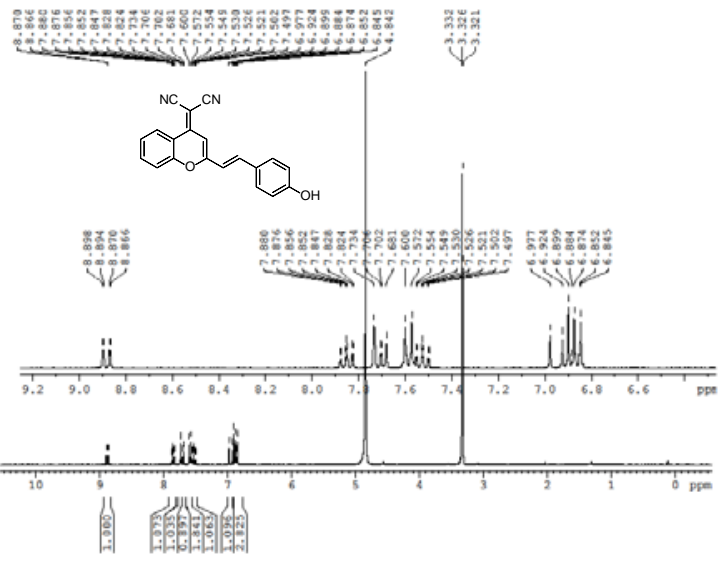

(b)

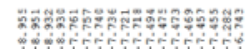

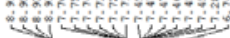

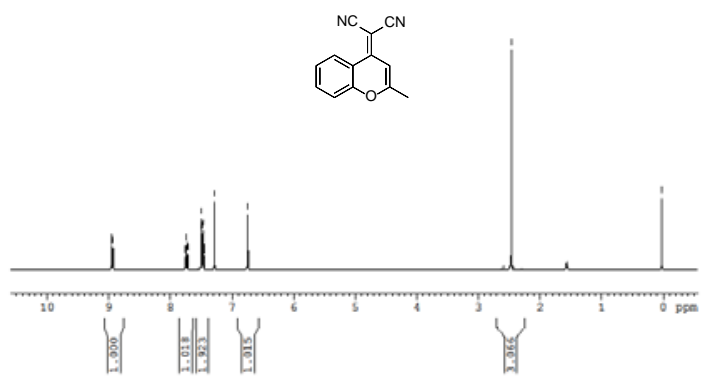

(d)

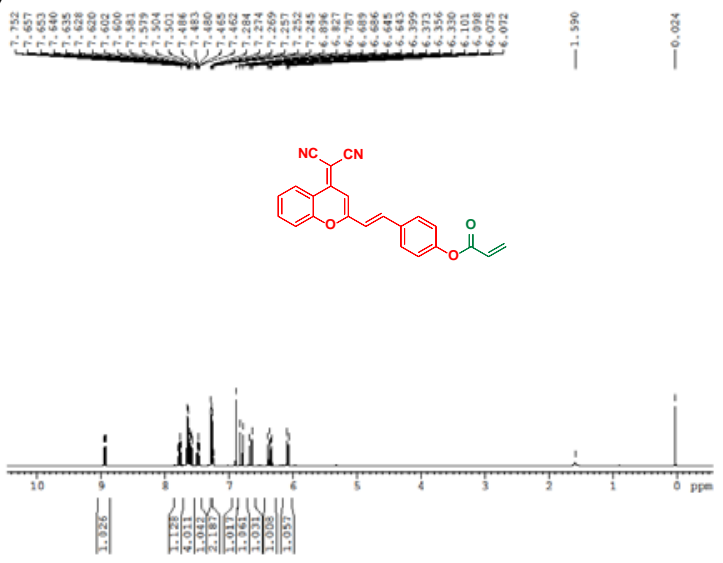

(e)
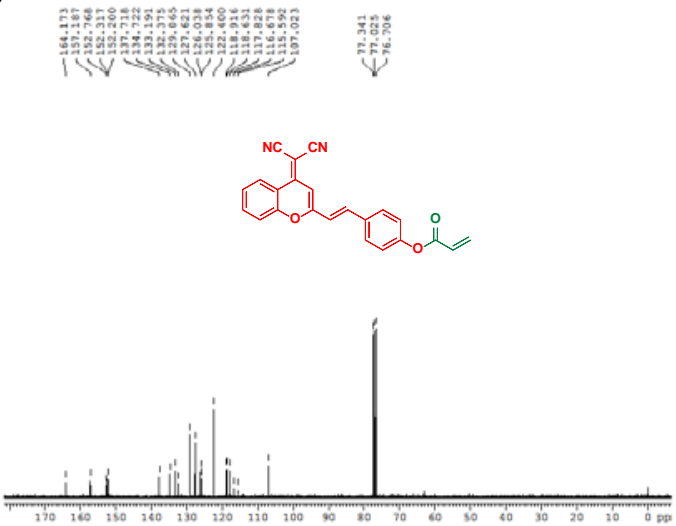

Figure S12. ${ }^{1} \mathrm{H}$ NMR of compound 4 (a), 5 (b), 1 (c), and TP-NIR (d) and ${ }^{13} \mathrm{C}$ NMR of TP-NIR (e). 